\title{
Effect of Plant Growth Promoting Bacteria from Crop Field on Growth Performance of Tomato
}

\author{
Diptirani Nanda* \\ Department of Botany, Rajsunakhala College, Rajsunakhala, Nayagarh, Odisha, India \\ *Corresponding author
}

\section{A B S T R A C T}

Keywords

Plant Growth,

Promoting Bacteria,

Crop Field, Tomato

Article Info

Accepted:

20 May 2018

Available Online:

10 June 2018
Plant growth promoting rhizobacteria (PGPR) have gained worldwide importance and have been identified in influencing the growth and yield of many plants. On account of that, an attempt was made in the present investigation to study plant growth promoting activities of bacteria isolated from rhizospheric region of different crop fields from khorda district, Odisha, India. A total of nine bacteria was isolated and they were further characterized for their different plant growth promoting activities like production of Indole acetic acid (IAA), HCN, Siderophore \& Phosphate solubilization. It was observed that all the bacterial isolates were positive for ammonia production but negative for $\mathrm{HCN}$ production. Bacterial isolates were again tried with tomato to study the growth performance. Among all the isolates DRN-3 and DRN-9 significantly increase the root length, shoot length and biomass of the plant in respect to control which was also statistically significant.

\section{Introduction}

Agriculture contributes to a major share of national income in many countries while ensuring food security and employment. Sustainable agriculture is extremely important in today's world because it offers the potential to meet future agricultural needs. In India, the Green Revolution-I during 1960s was aimed at increasing productivity of crops through application of fertilizer and introduction of high yield varieties. However with time, application of more agrochemicals like fertilizer, pesticides, herbicide and weedicide the soil health was drastically affected having destroyed nature's mechanism of fertilizing soil, controlling pests etc. through the destruction of diversity. Chemical fertilizers and pesticides also accumulated in the environment causing pollution, bioaccumulation \& biomagnifications of pollutants in the ecosystem and spread disease (Gerhardson, 2002).

The zone of soil directly surrounding the root system is referred as rhizosphere (Walker et al., 2003), while the term "rhizobacteria" implies a group of rhizosphere bacteria competent in colonizing the root environment (Kloepper et al., 1991). Root colonization is influenced by many factors: biotic; such as genetic traits of the host plant and the colonizing organism or abiotic; such as growth substrate, soil humidity, soil $\mathrm{pH}$, rhizosphere 
$\mathrm{pH}$, temperature and for this reason any soil bacteria cannot colonize root system. Whipps (2001) reported that in order to colonize the rhizosphere during an extended period characterized by strong microbial competition and exert plant growth promoting traits, soil bacteria need to be rhizosphere competent. Plant Growth-Promoting Rhizobacteria (PGPR) is defined as naturally occurring free living soil bacteria that aggressively colonize plant roots and benefit plants by providing growth promotion \& development via production and secretion of various regulatory chemicals in the vicinity of the rhizosphere. There are number of mechanisms used by PGPR for enhancing plant growth and development in diverse environmental conditions. According to Kloepper and Schroth (1981) PGPR mediate plant growth promotion by the alteration of the whole microbial community in rhizosphere niche through the production of various substances. PGPR enhances plant growth by phosphate solubilization, IAA production, siderophore, production, biological nitrogen-fixation, $\mathrm{HCN}$ production, cytokinins and gibberellic acid production (Glick, 1995). So PGPR increase germination percentage, seedling vigor, root and shoot growth, total biomass of plants, seed weight, early flowering grains, fodder and fruit yields, that can serve as a source as 'biofertilizers'. One of the mechanism used PGPR affect growth is antagonism against phytopathogenic microorganisms by production of siderophores (Pahari et al., 2017), which are low molecular weight phenolic compound or citric acid derivatives that chelates to iron, preventing the growth of soil borne fungal pathogens. So the use of siderophore producing rhizobacteria as a biofertilizer is one of the best modern tools for agriculture and it is a gift of our modern agricultural science.

On account of that, the present investigation has been undertaken to isolate the potential
Plant growth promoting rhizobacteria (PGPR) from different locations of Khorda district, Odisha and study their effect on growth of Tomato in pot culture method.

\section{Materials and Methods}

\section{Sample collection and bacterial isolation}

Soil samples were collected aseptically from the Rhizospheric region of different crop fields from different locations of Khorda district, Odisha. Top layer of soil (about $1 \mathrm{~cm}$ ) was removed and five samples each of about $10 \mathrm{gm}$, was collected at a depth of 10 to $20 \mathrm{~cm}$ from five spots of each location. Samples were mixed thoroughly and put in polythene packets with proper levels and transported to the laboratory. Collected soil samples were air dried and subjected to the isolation of bacteria by serial dilution method. A total of nine bacterial isolates were isolated from the rhizospheric soil sample by spread plate technique and named as DRN-1 to DRN-9.

\section{Morphological characterization of the bacterial isolates}

Morphological characterization of the bacterial isolates carried out by their colony characteristics like Shape, colour, margin, elevation on Nutrient Agar basal medium and Gram's staining. Gram staining followed by microscopic observation of all the bacterial isolates were done for Gram's variability, morphology and arrangement of bacteria.

\section{In vitro screening of isolates for different plant growth promoting characters}

Plant growth promoting activities of the bacterial isolates were tested in vitro. The PGP activities included IAA production, Phosphate solubilization, Hydrogen cyanide production and ammonia production, which was determined using following standard methods. 


\section{Indole acetic acid (IAA) production}

The test is used to check ability of the organisms to form indole from tryptophan or to detect the presence of enzyme tryptophanase which converts tryptophan to indole.

The test was performed by inoculating the bacterial cultures into tubes containing tryptone broth incubated at $30 \pm 1^{\circ} \mathrm{C}$ for $72 \mathrm{~h}$. After inoculation, Kovac's or Salkowski's reagent was added (1:1 by volume) and mixed to check for indole production which was indicated by a pink ring at the interface of the two solutions. Absence of pink ring indicated negative result.

\section{Ammonia production}

The organisms were inoculated in peptone water and incubated for $72 \mathrm{~h}$. Few drops of Nessler's Reagent were added to the culture broth. Appearance of reddish brown colour of the broth indicated positive result.

\section{Phosphate Solubilization}

Many soil microorganisms especially PGPR were able to solubilize unavailable forms of bound Phosphate. In a preliminary evaluation of the ability to solubilize tricalcium phosphate, the isolated strains were tested in National botanical research institute of phosphate growth medium (NBRIP) containing $(\mathrm{gm} / \mathrm{l}) 10 \mathrm{gm}$ glucose, $5 \mathrm{gm}$ $\mathrm{Ca}_{3}\left(\mathrm{PO}_{4}\right)_{2}, 5 \mathrm{gm} \quad \mathrm{MgCl}_{2} \cdot 6 \mathrm{H}_{2} \mathrm{O}, \quad 0.25 \mathrm{gm}$ $\mathrm{MgSO}_{4} \cdot 7 \mathrm{H}_{2} \mathrm{O}, \quad 0.2 \mathrm{gm} \mathrm{KCl}, \quad 0.1 \mathrm{gm}$ $\left(\mathrm{NH}_{4}\right)_{2} \mathrm{SO}_{4}$, and $1.5 \%$ agar, $(\mathrm{pH} 7.0)$.

For the agar plate assay, a loop full of each culture was placed on the centre of agar plates and incubated at $30 \pm 0.1^{\circ} \mathrm{C}$ for 5 days. Plates were checked for clear halos around colonies indicating solubilization of the turbid tricalcium phosphate.

\section{Production of Hydrogen Cyanide}

The isolates were further screened for their $\mathrm{HCN}$ producing abilities so as to detect the antagonistic activity of bacteria towards the soil fungal phytopathogens (Bashan and Holguin, 1997a).

Screening of bacterial isolates for hydrogen cyanide (HCN) production was done as per methodology described by Castric (1975). Bacterial cultures were streaked on nutrient agar medium containing $4.4 \mathrm{gm} / \mathrm{l}-1$ of glycine. A Whatman filter paper No. 1 soaked in $0.5 \%$ picric acid solution (in $2 \%$ sodium carbonate) was placed inside the lid of a plate. Plates were sealed with parafilm and incubated at $30 \pm 0.1{ }^{\circ} \mathrm{C}$ for 4 days. Development of light brown to dark brown colour indicated HCN production.

\section{Production of siderophores}

This assay was carried out based on the competition for iron between the ferric complexes of an indicator dye, chrome azurol $\mathrm{S}$ (CAS) and the siderophores produced by bacteria which apparently have a higher affinity for chelating $\mathrm{Fe}^{+3}$ of CAS. Siderophore production by rhizobacterial isolates was detected as described by Schwyn and Neilands (1987).

The assay was performed by using CAS agar medium which contains the ternary complex $\mathrm{CAS} / \mathrm{Fe}^{+3} /$ hexa decyltrimethyl-ammonium bromide as an indicator. Autoclaved CAS agar medium was poured in each Petri dish. The rhizobacterial inoculum was spot inoculated in the medium. The plates were incubated in the dark at $30^{\circ} \mathrm{C}$ for 7 days.

The CAS agar colour changed from blue to orange with clear halos surrounding a bacterial colony was scored as positive for siderophore production. 
Evaluation of Plant growth promoting rhizobacterial isolates (PGPR) on growth of Tomato

Bacterial isolates were further tried with tomato for determination of effect on plant growth in pot culture method. The seeds of tomato (BT-10) were soaked overnight in water, surface sterilized with $0.2 \% \mathrm{HgCl}_{2}$ solution for 2-3 min. and rinsed thoroughly in sterile distilled water for six times.

After that the seeds were soaked in $10 \mathrm{ml}$ of the bacterial suspension $\left(10^{9} \quad \mathrm{CFU} / \mathrm{ml}\right)$ containing 2\% Carboxy methyl cellulose (CMC) as an adhesive. A control set was run as seeds treated with sterile blank nutrient broth amended with CMC served as control.

Three seeds were sown at 4 to $5 \mathrm{~cm}$ depth of soil in each pot and water level in each pot was maintained. After 45 days the total chlorophyll content in leaf was measured by using the method stated by Arnon (1949). Growth parameters like root length, shoot length and total fresh biomass were recorded after harvesting of the plant.

\section{Statistical analysis}

All the experiment was done in triplicate and the data was analyzed statistically by one way ANOVA at $p<0.05$ significant level.

\section{Results and Discussion}

A total of nine morphologically distinct colonies were isolated from the different rhizosphere soil samples. They were found either circular or irregular, white or off-white; raised or flat elevation; entire or undulate margin. The bacterial isolates were further tested for their Gram's stain variability test. It was found that all the bacterial isolates were Gram positive in nature and rod shaped (Table 1).
The bacterial isolates were further characterized for their different plant growth promoting activities because bacteria colonizing at the rhizospheric region of plant roots and enhancing plant growth are referred to as plant growth-promoting rhizobacteria (PGPR).

They are known to improve plant growth by various direct and indirect mechanisms (Glick, 1995).

In the present investigation it was found that five bacterial isolates i.e. DRN-1, DRN-2, DRN-4, DRN-7 and DRN-9 were positive for siderophore production.

Because siderophores production by rhizosphere inhabitants not only improve rhizosphere colonization of producer strain but also plays an important role in iron nutrition of plant (Vansuyt et al., 2007) and antagonism against phytopathogens (Chincholkar et al., 2006; Pahari et al., 2017).

Among all the bacterial isolates, DRN-1, DRN-3, DRN-5 and DRN-9 were positive for IAA production. IAA in the rhizosphere depends on the availability of precursors and uptake of microbial IAA by plant (Arshad and Frankenberger, 1991).

On NBRIP agar medium, five of the bacterial isolates i.e. DRN -1, DRN -2, DRN -3, DRN-6 and DRN-9 showed sharp halo zones (Table 2) because microorganisms were capable of producing a clear zone due to $\mathrm{P}$ solubilization in the surrounding (Ngomle et al., 2014).

Furthermore all the bacterial isolates also exhibited strong production of ammonia from peptone water (Table 2) which is another important trait of PGPR and taken up by plants as a source of nitrogen for their growth (Ahmad et al., 2008). None of the isolates were positive for $\mathrm{HCN}$ production. 
Table.1 Morphological characterization of the bacterial isolates

\begin{tabular}{|c|c|c|c|c|c|c|}
\hline Isolate No. & Shape & Colour & Elevation & Margin & Consistency & Gram's reaction \\
\hline DRN-1 & Irregular & Off-white & Flat & Undulate & Non gummy & Gram Positive rod \\
\hline DRN -2 & Irregular & White & Flat & Undulate & Non gummy & Gram Positive rod \\
\hline DRN -3 & Circular & Off-white & Flat & Entire & Non gummy & Gram Positive rod \\
\hline DRN -4 & Irregular & White & Flat & Undulate & Non gummy & Gram Positive rod \\
\hline DRN -5 & Circular & White & Flat & Undulate & Non gummy & Gram Positive rod \\
\hline DRN-6 & Circular & Off-white & Raised & Undulate & Non gummy & Gram Positive rod \\
\hline DRN -7 & Irregular & Off-white & Flat & Undulate & Non gummy & Gram Positive rod \\
\hline DRN -8 & Circular & Off-white & Flat & Undulate & Non gummy & Gram Positive rod \\
\hline DRN-9 & Irregular & Off-white & Flat & Undulate & Non gummy & Gram Positive rod \\
\hline
\end{tabular}

Table.2 Plant growth promoting functions of the isolates

\begin{tabular}{|c|c|c|c|c|c|c|c|c|c|}
\hline \multirow[t]{2}{*}{ Test } & \multicolumn{9}{|c|}{ Isolate No. } \\
\hline & DRN-1 & DRN-2 & DRN-3 & DRN-4 & DRN-5 & DRN-6 & DRN-7 & DRN-8 & DRN-9 \\
\hline $\begin{array}{c}\text { Siderephore } \\
\text { production }\end{array}$ & + & + & - & + & - & - & + & - & + \\
\hline $\begin{array}{c}\text { HCN } \\
\text { production }\end{array}$ & - & - & - & - & - & - & - & - & - \\
\hline $\mathrm{NH}_{3}$ production & + & + & + & + & + & + & + & + & + \\
\hline IAA production & + & - & + & - & + & - & - & - & + \\
\hline $\begin{array}{c}\text { Phosphate } \\
\text { solubilization }\end{array}$ & + & + & + & - & - & + & - & - & + \\
\hline
\end{tabular}

Table.3 Effect of Plant growth promoting rhizobacterial isolates Tomato in pot

\begin{tabular}{|l|l|l|l|l|}
\multicolumn{1}{|c|}{ Isolate No. } & Root length $(\mathrm{cm})$ & $\begin{array}{c}\text { Shoot length } \\
(\mathbf{c m})\end{array}$ & $\begin{array}{c}\text { Biomass of root } \\
(\mathbf{g m})\end{array}$ & $\begin{array}{c}\text { Biomass of shoot } \\
(\mathrm{gm})\end{array}$ \\
\hline Control & $16.33 \pm 1.45$ & $56.00 \pm 1.15$ & $10.11 \pm 0.93$ & $27.76 \pm 1.08$ \\
\hline DRN-1 & $20.67 \pm 0.67$ & $72.23 \pm 2.80$ & $21.85 \pm 1.27$ & $51.91 \pm 1.81$ \\
\hline DRN -2 & $21.33 \pm 1.33$ & $65.90 \pm 0.58$ & $18.43 \pm 0.39$ & $49.07 \pm 1.41$ \\
\hline DRN -3 & $22.33 \pm 0.88$ & $81.00 \pm 2.08$ & $21.61 \pm 0.44$ & $52.38 \pm 1.12$ \\
\hline DRN -4 & $22.00 \pm 1.20$ & $65.33 \pm 1.45$ & $18.52 \pm 0.51$ & $46.38 \pm 0.66$ \\
\hline DRN -5 & $22.67 \pm 0.88$ & $84.00 \pm 1.52$ & $21.40 \pm 0.45$ & $49.73 \pm 1.94$ \\
\hline DRN-6 & $20.00 \pm 1.54$ & $71.00 \pm 1.52$ & $13.63 \pm 0.60$ & $41.87 \pm 1.76$ \\
\hline DRN -7 & $22.1 \pm 0.36$ & $71.33 \pm 2.33$ & $12.50 \pm 0.59$ & $35.17 \pm 1.68$ \\
\hline DRN -8 & $22.83 \pm 1.89$ & $68.33 \pm 1.20$ & $14.33 \pm 0.85$ & $39.10 \pm 1.99$ \\
\hline DRN-9 & $23.63 \pm 0.31$ & $89.33 \pm 1.85$ & $21.67 \pm 0.45$ & $59.74 \pm 0.77$ \\
\hline *Values represent mean three replications and results were significant at $<<0.05$ &
\end{tabular}


Table.4 Total chlorophyll content (mg/gm, FW) Of Tomato plant

*FW= Fresh Weight

\begin{tabular}{|l|l|}
\hline Isolate No. & Total Chlorophyll (mg/gm FW) \\
\hline Control & $0.10 \pm 0.02$ \\
\hline DRN-1 & $0.29 \pm 0.06$ \\
\hline DRN -2 & $0.27 \pm 0.05$ \\
\hline DRN -3 & $0.15 \pm 0.012$ \\
\hline DRN -4 & $0.18 \pm 0.011$ \\
\hline DRN -5 & $0.27 \pm 0.022$ \\
\hline DRN-6 & $0.16 \pm 0.05$ \\
\hline DRN -7 & $0.24 \pm 0.011$ \\
\hline DRN -8 & $0.14 \pm 0.02$ \\
\hline DRN-9 & $0.32 \pm 0.014$ \\
\hline
\end{tabular}

*Values represent mean three replications and results were significant at $\mathrm{p}<0.05$

In the present investigation, it was also found that all the plant growth promoting rhizobacterial isolates significantly increase the root length, shoot length and biomass of the tomato plant in respect to control. Maximum root length $(22.63 \mathrm{~cm})$ and shoot length $(89.33 \mathrm{~cm})$ was observed in case of DRN-9 treatments whereas in control, the root length and shoot length was $16.33 \mathrm{~cm}$ and $56.00 \mathrm{~cm}$ respectively (Table 3 ).

Similarly in case of biomass, the maximum fresh root biomass i.e. $21.85 \mathrm{gm}$ was found in DRN-1 treatments and maximum shoot biomass i.e. $\mathbf{5 9 . 7 4}$ gm was recorded in DRN-9 treatments (Table 3). Moreover, all the rhizobacterial isolates also significantly increase the chlorophyll content of leaf in respect to control (Table 4). Actually it is a well-established fact that overall plant growth and root development influenced by improved phosphorous nutrition. A large number of evidence suggests that PGPR enhance the growth, plant height, and biomass (Herman et al., 2008). So, use PGPR as a bio-inoculant is a novel and potential tool for providing substantial benefits to the agriculture. These beneficial, free-living bacteria enhance emergence, colonize roots, stimulate growth and enhance yield.

\section{Acknowledgement}

The author thankfully acknowledge to Department of Microbiology, OUAT and Dr. Avishek Pahari, OUAT for the help during the period of study. The authors have no conflict of interest to declare.

\section{References}

Ahmad. F, Ahmad, I. and Khan, M.S. 2008. Screening of free-living rhizospheric bacteria for their multiple plant growth promoting activities. Microbiological research., 163(2): 173-181.

Arnon, D.I. 1949. Copper enzymes in isolated chloroplasts, polyphenoxidase in Beta vulgaris. Plant Physiol., 24: 1-15.

Arshad, M. and Frankenberger, W.T. 1991. Microbial production of plant hormones, Plant Soil., 133: 1-8.

Bashan, Y. and Holguin, G. 1997a. Azospirillum-plant relationships, environmental and physiological advances (1990-1996), Canadian Journal of Microbiology., 43: 103-121.

Chincholkar, S.B., Chaudhari, B.L., Rane, M.R. and Sarode, P.O. 2006. Fungal phytopathogen suppression using Siderophoregenic bioinoculants. 
Biological Control of Plant Diseases, 401.

Gerhardson, B. 2002. Biological substitutes for pesticides, Trends in Biotechnology., 20:338-343.

Glick, B.R. 1995. The enhancement of plant growth by free-living bacteria. Canadian Journal of Microbiology., 41(2): 109-117.

Herman, M.A.B., Nault, B.A. and Smart, C.D. 2008. Effects of plant growthpromoting rhizobacteria on bell pepper production and green peach aphid infestations in New York, Crop Protectection., 27: 996-1002.

Kloepper, J.W. and Schroth, M.N. 1981. Relationship of in vitro antibiosis of plant growth promoting rhizobacteria to plant growth and the displacement of root microflora, Phytopathology., 71: 1020-1024.

Kloepper, J.W., Zablotowick, R.M., Tipping, E.M. and Lifshitz, R. 1991. Plant growth promotion mediated by bacterial rhizosphere colonizers. In: Keister, D.L., Cregan, P.B. (Eds.), The Rhizosphere and Plant Growth. Kluwer Academic Publishers, Dordrecht, Netherlands, pp. 315-326.

Ngomle, S., Bhattacharya, P.M., Roy, A. and Ambesh, B.S. 2014 Isolation and screening of phosphate solubilizing
Bacteria from different crop rhizosphere. The Ecoscan., 6:505-509.

Pahari, A. and Mishra, B.B. 2017. Characterization of Siderophore Producing Rhizobacteria and Its Effect on Growth Performance of Different Vegetables.

Int.J.Curr.Microbiol.App.Sci. $\quad$ 6(5): 1398-1405.

Pahari, A., Pradhan, A., Nayak, S.K. and Mishra, B.B. 2017. Bacterial Siderophore as a Plant Growth Promoter. J.K. Patra et al., (eds.), Microbial Biotechnology. Springer Nature Singapore., pp-163-180.

Schwyn, B. and Neilands, J.B. 1987. Universal chemical assay for the detection and determination of siderophores. Analytical biochemistry., 160(1):47-56.

Vansuyt, G., Robin, A., Briat, J.F., Curie, C. and Lemanceau, P. 2007. Iron acquisition from $\mathrm{Fe}$-pyoverdine by Arabidopsis thaliana. Molecular PlantMicrobe Interactions., 20(4):441-447.

Walker, T.S., Bais, H.P., Grotewold, E. and Vivanco, J.M. 2003. Root exudation and rhizosphere biology, Plant Physiology., 132: 44-51.

Whipps, J.M. 2001. Microbial interactions and biocontrol in the rhizosphere, Journal of Experimental Botany., $52: 487-511$.

\section{How to cite this article:}

Diptirani Nanda. 2018. Effect of Plant Growth Promoting Bacteria from Crop Field on Growth Performance of Tomato. Int.J.Curr.Microbiol.App.Sci. 7(06): 2213-2219. doi: https://doi.org/10.20546/ijcmas.2018.706.262 